\title{
REVENUE SHARING OR PROFIT SHARING ? AKUNTAN ALASANNYA
}

\author{
Maharani $^{1}$, Rianti Daud ${ }^{2}$, Niswatin $^{3}$ \& La Ode Rasuli ${ }^{4}$ \\ ${ }_{1,2,3 \& 4}$ Universitas Negeri Gorontalo, Indonesia \\ Email: rani12352@gmail.com, riantidaud@gmail.com, niswatin@ung.ac.id
}

\begin{abstract}
ABSTRAK
Penelitian ini bertujuan untuk melihat apakah metode bagi hasil yang digunakan oleh bank-bank syariah di Kota Gorontalo. Metode yang digunakan untuk melihat seperti apa bank syariah secara umum menerapkan metode bagi hasil revenue sharing atau profit sharing menggunakan metode sampling dalam menentukan objeknya. Sampel penelitian ini adalah Bank Muamalat cabang Kota Gorontalo dan Bank Syariah Mandiri Cabang Kota Gorontalo. Penelitian ini dilakukan dengan mewawancarai staf bank terkait, dan juga melakukan dokumentasi terhadap dokumen-dokumen berupa laporan keuangan secara umum terhadap sampel penelitian. Hasil penelitian ini menunjukan bahwa bank-bank syariah terkhusus di Gorontalo dan pada umumnya di Indonesia sendiri menggunakan revenue sharing dalam metode bagi hasil mudharabah dibandingkan dengan profit sharing yang banyak digunakan oleh bank syariah yang ada di luar negeri misalkan Malaysia.
\end{abstract}

Kata Kunci: Revenue Sharing, Revenue Margin, Mudharabah.

\begin{abstract}
This research aims to observe which method is used on mudharabah by Islamic banks in the capital of Gorontalo. The method used to observe that Islamic banks in generally using revenue sharing or profit sharing method we use the sampling methods to determine the object. The sample of this research are Muamalat Bank and Bank Mandiri Syariah. This research was conducted by interviewing the bank's staff, and also used documentation method of documents such as general financial statements. The results of this study indicate that Islamic banks especially in Gorontalo and generally in Indonesia itself, uses revenue sharing method in the mudharabah, compared to profit sharing that is widely used on inertnational Islamic banks such as Malaysia.
\end{abstract}

Keywords: Revenue Sharing, Revenue Margin, Mudharabah. 


\section{PENDAHULUAN}

Fakta bahwa masyarakat luas kurang paham akan akuntansi syariah terlebih lagi terkait akad-akad yang ada di dalam transaksi akuntansi syariah membuat masyarakat enggan menabung di bank syariah. Tidak mengerti, tidak mau mencari tahu atau bahkan menyamaratakan antara perbankan syariah dan konvensional yang notabenenya berbeda di beberapa aspek. Pernyataan ini sejalan dengan Ahmad dan Haron (2002) yang menyatakan bahwa sebagian masyarakat Muslim itu belum paham akan sistem syariah ini namun, terbalik dengan umat non-Muslim mereka tahu bahwa umat Muslim itu sebenarnya tidak diijinkan menggunakan bank konvensioanl dikarenakan bunga yang diterapkan dalam sistem perbankan konvensional.

Perbankan syariah dikenal dengan Islamic Banking yang pada awalnya dikembangkan sebagai suatu respon dari kelompok ekonomi dan praktisi yang berlingkup syariah. Sejak adanya revisi Undang-undang No. 10 Tahun 1998 tentang perbankan terdapat beberapa perubahan yang memberikan peluang yang lebih besar bagi pengembangan perbankan syariah. Dari Undang-undang tersebut menerangkan bahwa sistem perbankan syariah dikembangkan dengan beberapa tujuan yakni memenuhi kebutuhan jasa perbankan bagi masyarakat yang tidak menerima konsep bunga, memenuhi kebutuhan akan produk dan jasa perbankan yang memiliki beberapa keunggulan komparatif berupa peniadaan pembebanan bunga, membuka peluang pembiayaan bagi pengembangan usaha berdasarkan prinsip kemitraan dengan menjaga hubungan investor yang harmonis. Sementara pada bank konvensional konsep yang diterapkan adalah hubungan debitur dan kreditur.

Melihat makin maraknya perbankan yang mulai masuk ke ranah syariah hal ini dapat dibuktikan dengan pernyataan Otoritas
Jasa Keuangan (OJK) bahwa pertumbuhan perbankan syariah mengalami peningkatan setiap tahunnya hingga pada tahun 2018 , hal ini diakibatkan semakin meningkatnya kesadaran masyarakat Muslim di Indonesia untuk beralih dari sistem ekonomi konvensional menuju sistem ekonomi syariah atau berdasarkan hukum Islam.

Kesadaran ini tidak hanya dikeranakan di negara Indonesia mayoritas beragama Islam dan terbanyak di dunia, akan tetapi juga karena adanya perasaan yang timbul dari pribadi-pribadi Muslim untuk menerapkan Islam secara kaffah. Seperti yang kita ketahui di dalam ilmu syariah terdapat Maqashid Syariah yang merupakan sebuah gagasan dalam hukum Islam bahwa syariah diturunkan Allah SWT untuk mencapai tujuan tujuan tertentu. Jadi dapat kita simpulkan bahwa perbankan syariah memiliki beberapa tujuan tertentu salah satunya untuk kemaslahatan umat.

Melihat salah satu fenomena bank syariah di Gorontalo yang sistem perbankan syariahnya memang masih sangat minim keberadaannya. Akan tetapi, tanda-tanda perkembangan dari bank syariah itu sendiri sudah mulai terlihat. Hal ini ditandai dengan adanya beberapa bank yang sudah berbasis syariah serta bank-bank konvensional yang sudah berani mengambil keputusan untuk membuat produk-produk syariah. Bank syariah mempunyai beberapa produk perbankan salah satunya yaitu produk akad mudharabah.

Mengenai apa itu mudharabah, pada paragraf 4 PSAK 2017 menjabarkan mengenai pengertian mudharabah dijelaskan tentang mudharabah dan jenis mudharabah. Mudharabah adalah akad kerjasama usaha antara dua pihak dimana pihak pertama (pemilik dana) menyediakan seluruh dana, sedangkan pihak kedua (pengelola dana) bertindak selaku pengelola, dan keuntungan dibagi diantara mereka sesuai kesepakatan sedangkan kerugian finansial hanya ditanggung oleh pemilik dana. 
Menurut Susana dan Prasetyanti (2011) pembiayaan mudharabah merupakan salah satu tonggak ekonomi syariah yang mewakili prinsip Islam untuk mewujudkan keadilan masyarakat melalui sistem bagi hasil. Adapun definisi Mudharabah menurut Sayyid (2013) adalah akad antara dua pihak dimana salah satu pihak mengeluarkan sejumlah uang (sebagai modal) kepada lainnya untuk diperdagangkan. laba dibagi sesuai dengan kesepakatan.

Dari kedua definisi di atas dapat ditarik kesimpulan bahwa pengertian mudharabah yaitu akad yang dilakukan oleh shahibul mal dengan mudharib untuk usaha tertentu dengan pembagian keuntungan sesuai kesepakatan. Keuntungan yang dituangkan dalam kontrak ditentukan dalam bentuk nisbah. Jika usaha yang dijalankan mengalami kerugian, maka kerugian itu ditanggung oleh shahibul mal sepanjang kerugian itu bukan akibat kelalaian mudharib. Namun jika kerugian itu diakibatkan karena kelalaian mudharib, maka mudharib harus bertanggung jawab atas kerugian tersebut.

Dalam produk mudharabah memiliki dua metode pembagian hasil usaha yaitu: profit sharing adalah perhitungan bagi hasil didasarkan kepada hasil bersih dari total pendapatan setelah dikurangi dengan biayabiaya yang dikeluarkan untuk memperoleh pendapatan tersebut. Revenue sharing, yaitu sistem bagi hasil yang dihitung dari total pendapatan pengelolaan dana tanpa dikurangi dengan biaya pengelolaan dana. Berdasarkan hal tersebut maka kami tertarik meneliti lebih lanjut persoalan tentang metode pembagian hasil dari perbankan syariah di Kota Gorontalo.

\section{TINJAUAN PUSTAKA}

\section{Akad Mudharabah}

Dalam Islam akad mudharabah dibolehkan, karena bertujuan untuk saling membantu antara rab al-mal (investor) dengan mudharib. Ibn Rusyd dari madzhab Maliki menyatakan bahwa, di perbolehkannya akad mudharabah merupakan suatu kelonggaran yang khusus. Meskipun mudharabah tidak secara langsung disebutkan oleh Al-Qur'an atau Sunnah, namun ia adalah sebuah kebiasaan yang diakui dan dipraktikkan oleh umat Islam, dan bentuk perdagangan semacam ini terus hidup sepanjang periode awal era Islam sebagai tulang punggung perdagangan karavan dan perdagangan jarak jauh.

Dasar hukum yang biasa digunakan oleh para Fuqaha tentang kebolehan bentuk kerjasama ini adalah firman Allah SWT dalam surah Al-Muzammil ayat 20 :

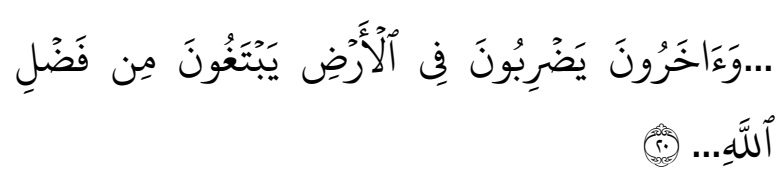

Artinya : "Tidak ada dosa bagimu untuk mencari karunia (rezeki hasil perdagangan) dari Tuhanmu...." (Q.S. Al-Muzammil ayat 20)

198:

Dan dalam surat Al-Baqarah ayat

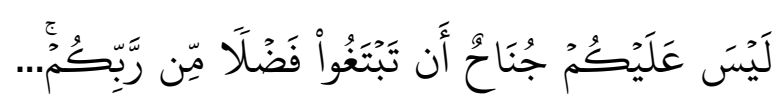

Artinya : “....dan sebagian mereka berjalan di bumi mencari karunia Allah....”. (Q.S. AlBaqarah ayat 198)

Di kedua ayat tersebut, terkandung makna diperbolehkannya akad mudharabah, yaitu bekerjasama mencari rezeki yang ditebarkan Allah SWT di muka bumi.

Sejalan dengan ini menurut Ahmad Asy Syarbasyi dalam Antonio (2001), AlMudharabah adalah akad kerja sama usaha antara dua pihak dimana pihak pertama (shahibul maal) menyediakan seluruh (100\%) modal, sedangkan pihak lainnya sebagai pengelola. Keuntungan usaha secara mudharabah dibagi menurut kesepakatan yang dituangkan dalam kontrak, sedangkan apabila rugi ditanggung oleh pemilik modal 
selama kerugian itu bukan akibat kelalaian si pengelola. Sedangkan kerugian itu diakibatkan karena kecurangan atau kelalaian si pengelola, si pengelola harus bertanggung jawab atas kerugian tersebut.

Adapula menurut PSAK 105 mudharabah adalah akad kerjasama usaha antara dua pihak dimana pihak pertama (pemilik dana) menyediakan seluruh dana, sedangkan pihak kedua (penegelola dana) bertindak selaku pengelola, dan keuntungan dibagi di antara mereka sesuai kesepakatan sedangkan kerugian finansial hanya ditanggung oleh pemilik dana.

Sebagaimana pula dengan yang dipaparkan pada Ebrahim dan Joo (2001), bahwa dalam akad mudharabah, tanggungan dari kerugian yang diakibatkan saat usaha itu dikelola atau berjalan ditanggung oleh pemilik dana, namun ketika kerugian dilakukan dengan sebuah kesengajaan oleh pengelola dana maka kerugian tersebut harus dibayarkan oleh pengelola kepada pemilik dana.

Jadi dapat disimpulkan secara umum mudharabah itu merupakan akad kerjasama antara dua belah pihak dimana pemilik dana/ penyedia dana sebagai pihak pertama dan pihak lainnya sebagai pengelola dan yang keuntungannnya dibagikan sesuai perjanjian/ akad awal terjadi, dengan kerugian ditanggung oleh penyedia/pemilik dana.

Menurut Prasetyo (2019) rukun mudharabah ada 4 yaitu:

a. Pelaku (transaktor). Investor biasa disebut dengan shahibul maal atau rabhul mal, sedangkan pengelola modal biasa disebut dengan mudharib. Memiliki kompetensi beraktivitas antara lain, mampu membedakan yang baik dan buruk serta tidak dalam keadaan tercekal seperti pailit.

1. Pelaku harus cakap hukum dan balig.
2. Pelaku akad mudharabah dapat dilakukan sesama atau dengan non muslim.

3. Pemilik dana tidak boleh ikut campur dalam pengelolaan usaha, tetapi ia boleh mengawasi.

b. Objek mudharabah (modal dan kerja)

1. Modal

1) Modal yang diserahkan dapat berbentuk uang/aset lainnya (dinilai sebesar nilai wajar), harus jelas dan jumlahnya.

2) Modal harus tunai dan tidak utang.

3) Modal harus diketahui dengan jelas jumlahnya sehingga dapat dibedakan dari keuntungannya.

4) Pengelola dana tidak diperkenankan untuk memudharabah-kan kembali modal mudharabahnya.

5) Pengelola tidak diperbolehkan untuk meminjamkan modal kepada orang lain kecuali atas seijin pemilik dana.

6) Pengelola dana memiliki kebebasan untuk mengatur modal menurut kebijaksanaan dan pemikirannya sendiri, selama tidak di larang syariah.

2. Kerja

1) Kontribusi pengelola dana dapat dibentuk keahlian keterampilan, selling skill, management skill, dll.

2) Kerja adalah hak pengelola dan tidak boleh di intervensi oleh pemilik dana.

3) Pengelola harus menjalankan dana harus menjalankan usaha sesuai syariah. 
4) Pengelola dana harus mematuhi semua ketetapan dalam kontrak.

5) Dalam hal pemilik dana tidak boleh melakukan kewajiban atau melakukan pelanggaran terhadap kesepakatan pengelola dana sedah menerima modal dan sudah bekerja maka pengelola dana berhak mendapatkan imbalan/ganti rugi/upah.

c. Ijab dan kabul

Ijab dan kabul atau persetujuan kedua belah pihak dalam mudharabah yang merupakan wujud dari prinsip sama-sama rela (an-taraddin minkum). Dalam hal ini, kedua belah pihak harus secara rela bersepakat untuk meningkatkan diri dalam akad mudharabah.

\section{d. Nisbah Keuntungan}

\section{Nisbah}

keuntungan

mencerminkan imbalan yang berhak diterima oleh kedua belah pihak yang terikat akad mudharabah. Syarat pembagian keuntungan dalam investasi mudharabah meliputi hal-hal sebagai berikut :

1. Nisbah adalah besaran yang digunakan untuk bagian keuntungan, mencerminkan imbalan hak yang diterima oleh kedua pihak yang bermudharabah atas keuntungan yang diperoleh.

2. Perubahan nisbah harus berdasarkan kesepakatan kedua belah pihak.

3. Pemilik dana tidak boleh meminta pembagian keuntungan dengan menyatakan nilai nominal tertentu karena dapat menimbulkan riba.

4. Harus diperuntuka bagi kedua belah pihak dan tidak boleh disyaratkan hanya untuk satu pihak.

5. Penyedia dana menanggung semua kerugian dari mudharabah dan pengelola tidak boleh menanggung kerugian apapun, kecuali diakibatkan dari kesalahan yang disengaja, kelalaian atau pelanggaran kesepakatan.

6. Sekiranya terjadi kerugian yang disebabkan oleh kelalaian mudharib maka mudharib wajib menanggung segala kerugian tersebut.

\section{Metode Pembagian Hasil Usaha}

Pembagian hasil usaha mudharabah dapat dilakukan berdasarkan prinsip bagi hasil atau bagi laba. Jika berdasarkan prinsip bagi hasil, maka dasar pembagian hasil usaha adalah laba bruto (gross profit) bukan total pendapatan usaha (omset). Sedangkan jika berdasarkan prinsip bagi laba, dasar pembagian adalah laba neto (netprofit) yaitu laba bruto dikurangi beban yang berkaitan dengan pengelolaan dana mudharabah.

Bagi hasil dalam sistem perbankan syariah merupakan ciri khusus yang ditawarkan kepada masyarakat dan di dalam aturan syariah yang berkaitan dengan pembagian hasil usaha harus ditentukan terlebih dahulu pada awal terjadinya kontrak (akad). Besarnya penentuan porsi bagi hasil antara kedua bela pihak ditentukan sesuai kesepakatan bersama dan harus terjadi dengan adanya kerelaan (an-taraddin) di masing-masing pihak tanpa adanya unsur paksaan (Putri, 2012).

Definisi lain dari bagi hasil adalah suatu cara pembagian hasil usaha antara penyedia dana dan pengelola dana. Pembagian hasil usaha ini dapat terjadi antara bank dengan penyimpan dana maupun antara bank dengan nasabah penerima dana. Mekanisme perhitungan bagi hasil yang diterapkan di dalam 
perbankan syariah terdiri dari dua sistem, yaitu :

\section{a. Profit Sharing (Bagi Laba)}

Bagi laba (profit sharing) adalah bagi hasil yang dihitung dari pendapatan setelah dikurangi biaya pengelolaan dana. Dalam sistem syariah pola ini dapat digunakan untuk keperluan distribusi hasil usaha lembaga keuangan syariah (Hardiwinoto, 2011). Jadi profit sharing merupakan perhitungan bagi hasil yang didasarkan kepada hasil bersih dari total pendapatan setelah dikurangi dengan biaya-biaya yang dikeluarkan untuk memperoleh pendapatan tersebut. Pada perbankan syariah istilah yang sering dipakai adalah profit and lost sharing, dimana hal ini dapat diartikan sebagai pembagian antara untung dan rugi dari pendapatan yang diterima atas hasil usaha yang telah dilakukan.

Sistem profit and lost sharing dalam pelaksanaannya merupakan bentuk dari perjanjian antara pemodal (investor) atau pengelola modal (entrepreneur) dalam menjalankan kegiatan usaha ekonomi, dimana di antara keduanya akan terikat kontrak bahwa di dalam usaha tersebut jika mendapatkan keuntungan akan dibagi antara kedua bela pihak sesuai nisbah kesepakatan di awal perjanjian.

Begitu pula apabila usaha mengalami kerugian akan di tanggung bersama sesuai porsi masing-masing. Kerugian bagi pemodal tidak mendapatkan kembali modal investasinya secara utuh ataupun keseluruhan sedangkan bagi pengelola modal tidak mendapatkan upah/hasil dari jerih payahnya atas kerja yang telah dilakukannya (Putri, 2012).
Keuntungan yang dapat didapat dari hasil usaha tersebut akan dilakukan pembagian setelah dilakukan perhitungan terlebih dahulu atas biaya-biaya yang telah dikeluarkan selama proses usaha. Keuntungan usaha dalam dunia bisnis bisa negatif artinya usaha merugi, positif berarti ada angka lebih sisa dari pendapatan dikurang biaya-biaya dan nol artinya antara pendapatan dan biaya menjadi balance. Keuntungan yang dibagikan adalah keuntungan bersih (net profit) yang merupakan kelebihan dari selisih atas pengurangan total cost terhadap total revenue (Dariah et al, 2015).

\section{b. Revenue Sharing}

Revenue pada perbankan syariah adalah hasil yang diterima oleh bank dari penyaluran dana (investasi) kedalam bentuk aktiva produktif, yaitu penempatan dana pada pihak lain. Hal ini merupakan selisih atau angka lebih dari aktiva produktif dengan hasil penerimaan bank.

Perbankan syariah memperkenalkan sistem pada masyarakat dengan istilah Revenue Sharing yaitu sistem bagi hasil yang dihitung dari total pendapatan pengelolaan dana tanpa dikurangi dengan biaya pengelolaan dana. Adapun pengertian lain dari revenue sharing dalam arti perbankan adalah perhitungan bagi hasil didasarkan kepada total seluruh pendapatan yang diterima sebelum dikurangi dengan biaya-biaya yang telah dikeluarkan untuk memperoleh pendapatan tersebut. Sistem revenue sharing berlaku pada pendapatan bank yang akan dibagikan dihitung berdasarkan pendapatan kotor (gross sales) yang digunakan dalam menghitung bagi hasil untuk produk pendanaan bank. 


\section{Maqashid Syariah}

Dalam kamus bahasa arab, maqshad dan maqashid berasal dari akar kata qashd. Maqshid adalah kata yang menunjukkan banyak (jama'), mufradnya maqshad yang berarti tujuan atau target. Syatibi mendefinisikan maqashid syariah dari kaidah berikut, sesungguhnya syariah bertujuan untuk mewujudkan kemaslahatan manusia di dunia dan akhirat. Imam AsySyatibi menjelaskan ada 5 bentuk maqashid syariah atau yang disebut dengan kulliyat alkhamsah (lima prinsip umum). Kelima maqashid tersebut yaitu :

1. Hifdzu Din (Melindungi Agama)

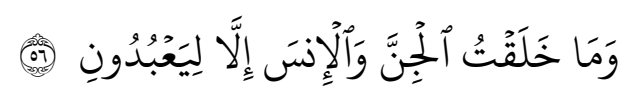

Artinya: "Dan aku tidak menciptakan jin dan manusia melainkan supaya mereka mengabdi kepada-Ku” (Q.S. Adz-Dzariyat ayat 56).

\section{Hifdzu Nafs (Melindungi Nyawa)}

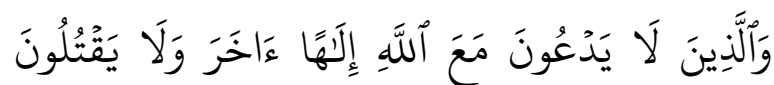

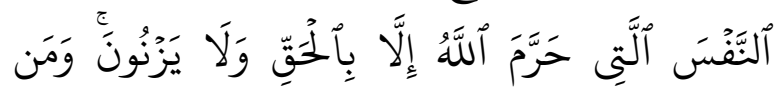

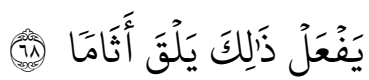

Artinya: "Tidak menyembah tuhan yang lain beserta Allah dan tidak membunuh jiwa yang diharamkan Allah (membunuhnya) kecuali dengan (alasan) yang benar, dan tidak berzina, barang siapa yang melakukan yang demikian itu, niscaya dia mendapat (pembalasan) dosa(nya)" (Q.S. Al-Furqan ayat 68 ).

\section{Hifdzu Aql (Melindungi Akal)}

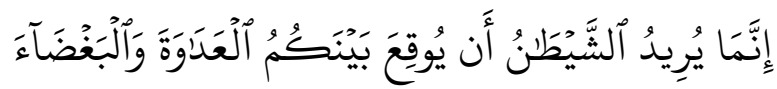

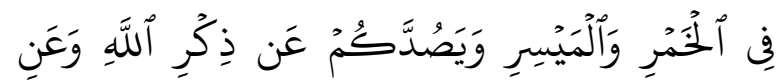

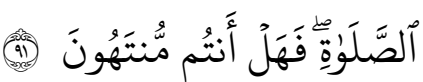

Artinya: "Sesungguhnya syaitan itu bermaksud hendak menimbulkan permusuhan dan kebencian di antara kamu lantaran (meminum) khamar dan berjudi itu, dan menghalangi kamu dari mengingat Allah dan sembahyang; Maka berhentilah kamu (dari mengerjakan pekerjaan itu" (Q.S. Al-Ma'idah ayat 91).

\section{Hifdzu mal (Melindungi Harta)}

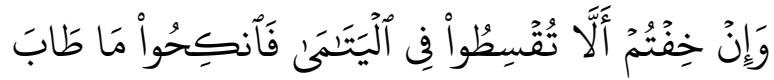

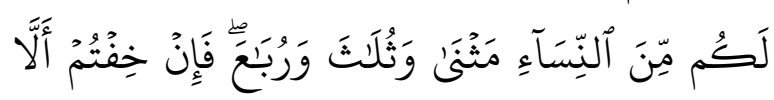

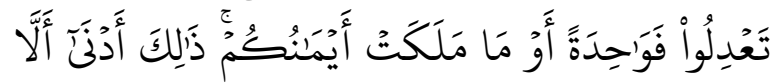

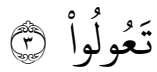

Artinya: "Dan jika kamu takut tidak akan dapat Berlaku adil terhadap (hak-hak) perempuan yang yatim (bilamana kamu mengawininya), Maka kawinilah wanitawanita (lain) yang kamu senangi : dua, tiga atau empat. kemudian jika kamu takut tidak akan dapat Berlaku adil. Maka (kawinilah) seorang saja, atau budak-budak yang kamu miliki. yang demikian itu adalah lebih dekat kepada tidak berbuat aniaya" (Q.S. An-Nisa ayat 3 ).

\section{Hifdzu Nasab (Melindungi Keturunan)}

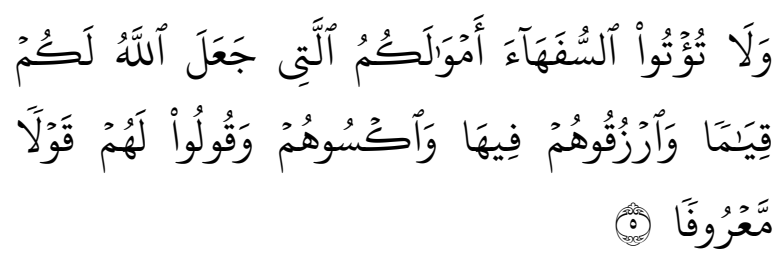

Artinya: "Dan janganlah kamu serahkan kepada orang-orang yang belum sempurna akalnya, harta (mereka yang ada dalam kekuasaanmu) yang dijadikan Allah sebagai pokok kehidupan. berilah mereka belanja dan pakaian (dari hasil harta itu) dan ucapkanlah kepada mereka kata-kata yang baik" (Q.S. An-Nisa ayat 5). 


\section{METODE PENELITIAN}

\section{Pendekatan Penelitian}

Pendekatan yang digunakan dalam penelitian ini adalah pendekatan kualitatif. Pendekatan kualitatif adalah suatu prosedur penelitian yang menghasilkan data deskriptif berupa kata-kata tertulis atau lisan orangorang dan perilaku yang dapat diamati. Pendekatan kualitatif memiliki karakteristik alami (natural serfing) sebagai sumber data langsung, deskriptif, proses lebih dipentingkan dari pada hasil.

Analisis dalam penelitian kualitatif cenderung dilakukan secara analisis induktif dan makna makna merupakan hal yang esensial (Moleong, 2016). Metode pengumpulan data yang digunakan adalah metode simak dan metode cakap dalam Saddhono (2012), yang selanjutnya menggunakan teknik simak libat cakap, teknik rekam, dan teknik catat.

Penelitian ini dilaksanakan di dua lokasi, yaitu di Bank Muamalat KC Gorontalo Jl. Ahmad Yani, dan di Bank Mandiri Syariah KC Gorontalo Jl. Ahmad Yani.

\section{Subjek Penelitian}

Subjek penelitian ini terdiri dari 2 staf Bank Syariah yang diambil dan merupakan pihak yang terlibat dengan produk bank syariah yaitu akad mudharabah dengan tujuan agar subjek dapat memberikan data secara tepat.

\section{Teknik Pengumpulan Data}

Teknik pengumpulan data yang digunakan dalam penelitian adalah teknik wawancara atau interview, dan dokumentasi.

Teknik wawancara yang digunakan dalam penelitian ini adalah wawancara mendalam. Wawancara mendalam merupakan cara mengumpulkan data atau informasi dengan cara langsung bertatap muka dengan informan, dengan maksud mendapatkan gambaran lengkap tentang topik yang diteliti. Wawancara dalam penelitian ini dilakukan untuk memperoleh data dan informasi mengenai produk akad mudharabah pada Bank Syariah.

Teknik pengumpulan data dengan menggunakan dokumentasi merupakan suatu teknik pengumpulan data dengan menghimpun dan menganalisis dokumendokumen, baik tertulis, gambar, maupun elektronik. Studi dokumen merupakan pelengkap dari penggunaan metode observasi dan wawancara dalam penelitian kualitatif. Hasil penelitian dari observasi atau wawancara, akan lebih kredibel dan dapat dipercaya kalau didukung oleh dokumendokumen dari narasumber (Sukmadinata, 2013). Dokumen yang kami pakai berupa contoh laporan keuangan dari pihak bank terkait, serta dokumen tambahan berupa laporan keuangan konsolidasi yang ada pada BEI yang dapat diakses secara daring.

\section{PEMBAHASAN}

Setelah ditemukan beberapa data yang diinginkan, baik dari hasil penelitian interview maupun dokumentasi, maka akan dianalisa temuan yang ada, serta menjelaskan tentang implikasi-implikasi dari hasil penelitian tentang upaya dari bank syariah di Kota Gorontalo dalam menerapkan metode bagi hasil (mudharabah) menggunakan revenue sharing ataukah profit sharing. Untuk teknik analisa sendiri dijelaskan dalam penelitian ini, peneliti menggunakan analisa kualitatif deskriptif (pemaparan) dan data yang diperoleh peneliti baik melalui interview maupun dokumentasi dari pihak-pihak yang mengetahui tentang data-data yang dibutuhkan dalam penelitian ini. Adapun hasil temuannya adalah sebagai berikut:

\section{Penggunaan Metode Revenue Sharing}

Saat peneliti melakukan observasi, peneliti menemukan upaya yang dilakukan oleh bank syariah yakni Bank Muamalat dan Bank Syariah Mandiri dalam menerapkan salah satu metode pembagian hasil usaha dari akad mudharabah itu sudah dilakukan 
dengan memikirkan kondisi perkenomian dan sosial masyarakat. Ini sesuai dengan apa yang sudah dikatakan oleh staf khusus kedua bank yang menyatakan bahwa yang digunakan bank tersebut adalah revenue sharing, bahkan kata mereka sebagian besar perbankan syariah di Indonesia itu banyak menggunakan revenue sharing.

Bagi Bank Muamalat sendiri yang merupakan pelopor bank syariah di Indonesia, pun sudah sejak awal menerapkan revenue sharing dalam metode bagi hasilnya. Di dalam penggunaan akad bagi hasil itu memang sebaiknya menggunakan profit sharing karena pihak bank sebagai pengelola dana, akan mendapatkan resiko yang kecil dibandingkan ketika menggunakan revenue sharing. Hal ini sesuai dengan cara pengambilan metode bagi hasil itu.

Untuk revenue sharing sebagai salah satu metode yang digunakan bank akan membagi hasil laba kotor pendapatan yang didapatkan oleh bank sebagai pengelola dana, tanpa pihak bank mengurangi biayabiaya serta beban-beban yang seharusnya ditanggung bank. Ini jelas memberikan kerugian pada bank. Dikarenakan setelah pembagian hasil laba pendapatan yang diterima bank berdasarkan nisbah yang telah ditentukan, bank masih harus membayar biaya serta beban perusahaan. Hal ini bisa dilihat dalam penjelasan PSAK 105 tentang mudharabah.

Hal berbeda jika bank menggunakan metode profit sharing, maka bank akan mendapatkan keuntungan karena bank hanya akan membagi hasil pendapatan laba bersih kepada pemberi dana. Sebagaimana yang telah diterangkan oleh Hardiwinoto (2011), bagi laba (Profit Sharing) adalah bagi hasil yang dihitung dari pendapatan setelah dikurangi biaya pengelolaan dana. Sejalan dengan Dariah et al (2015), keuntungan yang dibagikan adalah keuntungan bersih (net profit) yang merupakan kelebihan dari selisih atas pengurangan total cost terhadap total revenue. Ada pula penelitian yang menyatakan bahwa pengaruh orang menabung pada bank adalah laba yang akan diterima atau return yang akan didapatkan dari penenaman dana atau investasi pada sebuah bank (Ahmad dan Haron, 2002).

Meski bank hanya mendapatkan sedikit keuntungan dari revenue sharing hal ini tidak serta merta menjadikan bank berpindah ke metode bagi hasil profit sharing yang memberikan keuntungan bagi pihak bank sebagai pengelola dana. Ini karena bank masih mengharapkan bertambahnya pengguna/nasabah dalam dunia perbankan di Indonesia khusunya Gorontalo. Meski sudah ditawarkan dengan metode bagi hasil revenue sharing, masyarakat masih belum bisa move on dari perbankan konvensional, terkhususnya masyarakat Gorontalo yang jumlahnya $>90 \%$ umat Islam pun juga dikenal daerah Gorontalo ini dengan istilah 'Serambi Madinah'-nya Indonesia.

Hal lain pula yang mendorong bank syariah untuk menerapkan sistem bagi hasil revenue sharing tidak semata-mata untuk menarik banyak nasabah untuk melakukan penanaman modalnya terhadap bank. Tetapi ada maksud dan tujuan yang sudah ditetapkan oleh bank syariah itu didirikan yang disebut dengan maqashid syariah. Maqashid syariah terdiri dari 5 yaitu AKUNTAN. Kelima maqashid tersebut adalah :

1. Hifdzu Din (Melindungi Agama)

2. Hifdzu Aql (Melindungi aKal)

3. Hifdzu Nasab (Melindungi KeturUNan)

4. Hifdzu mal (Melindungi HarTA)

5. Hifdzu Nafs (Melindungi Nyawa)

Inilah maksud yang dituju oleh bank syariah sesungguhnya. Bank syariah itu tidak berorientasi pada keuntungan semata, akan tetapi berdasarkan pada maqashid syariah yang berpegang teguh pada apa yang diturunkan Allah SWT. Kami menyimpulkan bahwa alasan paling krusial bank 
menggunakan metode bagi hasil revenue sharing itu dikarenakan maqashid syariah yang secara tidak langsung belum disadari oleh bank tersebut. Tapi dilihat dari informasi-informasi yang diberikan maka itu akan merujuk kepada alasan as-syari'ah yang disebut sebagai maqhashid syariah.

Tidak berbeda jauh dengan pendapat dari Yusof et.al (2015), yang menyatakan bahwa negara-negara GCC itu sesungguhnya dalam menjalankan perbankan kembali kepada maqashid syariah. Sehingga ini juga tidak berbeda jauh dari apa yg dilakukan perbankan syariah di Indonesia saat ini. Meski yang dilakukan itu awalnya hanya untuk menarik nasabah dan meningkatkan iklim perbankan syariah di Indonesia. Tapi tanpa disadari bahwa informasi-infomasi tersebut dilakukan semata-mata karena maqashid syariah. Berdasarkan beberapa teori serta pengertian mengenai profit sharing dan revenue sharing dapat dilihat beberapa perbedaannya dalam tabel berikut ini.

Tabel 1. Perbedaan Implementasi Profit Sharing dan Revenue Sharing

\begin{tabular}{ccll}
\hline No & Profit Sharing & \multicolumn{3}{c}{ Revenue Sharing } \\
\hline 1. & Profit sharing adalah bagi keuntungan atau laba. & $\begin{array}{l}\text { Revenue sharing berarti pembagian } \\
\text { penghasilan atau pendapatan. }\end{array}$ & hasil,
\end{tabular}

2. Perhitungan bagi hasil didasarkan kepada hasil bersih dari total pendapatan setelah dikurangi dengan biaya-biaya yang dikeluarkan untuk memperoleh pendapatan tersebut atau pula beban-beban yang harus ditanggung pada pengelolaan dana tersebut. Revenue Sharing, yaitu sistem bagi hasil yang dihitung dari total pendapatan pengelolaan dana tanpa dikurangi dengan biaya pengelolaan dana dan atau beban-beban dalam mengelola dana tersebut.

3. Di antara keduanya (pemilik dana dan pengelola) akan terikat kontrak bahwa di dalam usaha tersebut jika mendapat keuntungan akan dibagi kedua pihak sesuai nisbah kesepakatan di awal perjanjian, dan begitu pula bila usaha mengalami kerugian akan ditanggung bersama sesuai porsi masing-masing modal yang ditanamkan*.

*Tipe mudharabah musyarakah
4. Keuntungan yang dibagikan adalah keuntungan bersih (net profit) yang merupakan kelebihan dari selisih atas pengurangan total cost terhadap total revenue.
Perbankan Syariah memperkenalkan sistem pada masyarakat dengan istilah Revenue Sharing, yaitu sistem bagi hasil yang dihitung dari total pendapatan pengelolaan dana tanpa dikurangi dengan biaya pengelolaan dana.

Sistem revenue sharing berlaku pada pendapatan bank yang akan dibagikan dihitung berdasarkan pendapatan kotor (gross sales), yang digunakan dalam menghitung bagi hasil untuk produk pendanaan bank.

5. Pada perbankan syariah istilah yang sering dipakai adalah profit and loss sharing, dimana hal ini dapat diartikan sebagai pembagian antara untung dan rugi dari pendapatan.
Revenue bagi bank adalah jumlah dari penghasilan bunga bank yang diterima dari penyaluran dananya atau jasa atas pinjaman maupun titipan yang diberikan oleh bank.

Sumber: Data Olahan (2021)

\section{KESIMPULAN}

Berdasarkan hasil riset dapat disimpulkan bahwa, akad mudharabah merupakan salah satu akad yang banyak dipakai dalam perbankan di Indonesia. Akad ini sendiri terbagi atas dua metode, dalam perhitungan pembagian hasil pendapatan mudharabah. Yakni profit sharing dan revenue sharing, dan yang paling banyak digunakan di Indonesia adalah revenue sharing, dikarena beberapa alasan yang telah dipaparkan di atas seperti alasan tersirat oleh pihak bank yakni, tetap menarik nasabah/ pelanggan ke bank untuk menanamkan dananya sebagai dana mudharabah. Alasan yang krusial pula, yang tidak dinyatakan tersitar oleh bank tetapi dapat dinilai dari informasi-informasi yang diberikan bahwa penggunanaan metode revenue sharing itu 
berlandaskan pada maqashid syariah dari penerapan akuntansi perbankan syariah pada bank-bank syariah selaku salah satu pelaku ekonomi Islam. Meski alasan krusial ini tidak dipaparkan oleh informan, tetapi informasi-informasi yang diberikan terpapar jelas dalam tujuan as-syari'ah yakni maqhashid syariah.

\section{DAFTAR PUSTAKA}

Ahmad, Norafifah., \& Haron, Sudin. (2002). Perceptions of Malaysian corporate customers towards Islamic banking products and services. International Journal of Islamic Financial Services. 3(4).

Antonio, Muhammad Syafii. 2001. Bank Syariah dari Teori ke Praktik. Gema Insani. Jakarta.

Dariah, Atih Rohaeti., Sundaya, Yuhka., \& Abdul Malik, Zaini. 2015. Optimizing Input and Output under the Scheme of Mudharabah. International Journal of Science and Research (IJSR), 4(5), p. 227-231.

Ebrahim, M. Shahid., \& Joo, Tan Kai. 2001. Islamic banking in Brunei Darussalam. International Journal of Social Economics, 28(4), p. 314-337.

Hardiwinoto. 2011. Analisis Komparasi Review Anda Profit Sharing Pada Sistem Mudharabah Pada PT. BPRS PNM Binama Semarang. Value Added, 7(2), p. 46-67.

Moleong, L. J. 2016. Metodologi Penelitian Kualitatif (Revisi). PT. Remaja Rosdakarya. Bandung.

Prasetyo, A. 2019. Akuntansi Keuangan Syariah. CV. Andi Offset. Yogyakarta.

Putri, Ghianisa Oktaria. 2012. Analisis Bagi Hasil Deposito Mudharabah Pada Bank Umum Syariah Di Indonesia. Skripsi Fakultas Ilmu Sosial dan Ilmu Politik Universitas Indonesia.

Saddhono, Kundharu. 2012. Kajian
Sosiolingustik Pemakaian Bahasa Mahasiswa Asing Dalam Pembelajaran Bahasa Indonesia Untuk Penutur Asing (BIPA) Di Universitas Sebelas Maret. Kajian Linguistik Dan Sastra, 24(2), p. 176-186.

Sayyid, S. 2013. Fiqih Sunnah 4 / Sayyid Sabiq ; Penerjemah: Abu Syauqina, Abu Aulia Rahma (Cet. 1). Tinta Abadi Gemilang. Jakarta.

Sukmadinata, N. S. 2013. Metode Penelitian Pendidikan. PT Remaja. Bandung.

Susana, Erni., \& Prasetyanti, Annisa. 2011. Pelaksanaan dan Sistem Bagi Hasil Pembiayaan al-Mudharabah Pada Bank Syariah. Jurnal Keuangan Dan Perbankan, 15(3), p. 466-478.

Yusof, R. M., Bahlous, M., \& Tursunof, H. 2015. Are Profit Sharing Rates of Mudharabah Account Linked to Interest Rates? An Investigation on Islamic Banks in GCC Countries. Jurnal Ekonomi Malaysia, 49(2), p. 77-86. 